\title{
SEPARATION OF OIL-IN-WATER EMULSION USING SLOTTED PORE MEMBRANE
}

\author{
P. D. Sutrisna ${ }^{1 *}$, F. S. Lingganingrum ${ }^{1}$, I G. Wenten ${ }^{2}$ \\ ${ }^{1}$ Chemical Engineering Department, Universitas Surabaya \\ Jalan Raya Kalirungkut, Tenggilis, Surabaya 60292 \\ ${ }^{2}$ Chemical Engineering Department, Institut Teknologi Bandung \\ Jalan Ganesha 10, Bandung 40132 \\ Email: pudod@ubaya.ac.id
}

\begin{abstract}
Nowadays, oil-in-water $(\mathrm{O} / \mathrm{W})$ emulsion has become an important topic in many industries. Petroleum industry is one of these industries. $\mathrm{O} / \mathrm{W}$ emulsion produced in crude oil recovery causes problems at different stages in petroleum industry. Produced water can not be injected again into the well, because it contains high concentrations of oil, grease and suspended particles. Recently, membrane technology has been applied in separation of $\mathrm{O} / \mathrm{W}$ emulsion. One membrane that has been developed special for oil filtration is slotted true surface filter. This research investigated influences of pore size and initial concentration of feed emulsion during oil filtration using slotted pore membrane. From the experiment, oil rejection will be higher if we use membrane with smaller pore size, emulsion with high stability and small trans membrane pressure. Based on the slot width it can be concluded that 33 microns membrane gives better oil rejection than 80 microns membrane. Initial concentrations of challenge emulsion also influence value of flux and oil rejection, which will also influence our decision to choose suitable membrane in relation with hydrophilicity of the membrane. During microfiltration process, there was deformation of oil particle through slot of membrane, which can be analyzed by observing size of oil drops in feed and permeate sides.
\end{abstract}

Keywords: emulsion, microfiltration, slotted pore membrane

\begin{abstract}
Abstrak
Saat ini penanganan limbah emulsi minyak dalam air menjadi topik penting di berbagai industri. Salah satunya adalah industri perminyakan. Emulsi yang dihasilkan dalam proses penambangan minyak mentah menimbulkan masalah pada beberapa tahapan proses di industri. Air yang mengandung minyak tidak dapat digunakan kembali untuk meningkatkan perolehan minyak karena mengandung minyak, lemak dan partikel tersuspensi dalam konsentrasi tinggi. Sehingga dibutuhkan proses pemisahan emulsi minyak dalam air. Akhirakhir ini teknologi membran telah digunakan untuk memisahkan emulsi tersebut. Salah satu membrane yang dikembangkan adalah membrane berslot seperti yang digunakan dalam penelitian ini. Penelitian ini telah berupaya mengamati pengaruh variasi ukuran pori dan konsentrasi umpan terhadap performa membrane berslot dalam memisahkan emulsi minyak dalam air. Dari percobaan, diperoleh hasil bahwa rejeksi membran terhadap minyak meningkat jika digunakan membrane dengan ukuran ori lebih kecil, emulsi dengan kestabilan yang tinggi, dan beda tekanan yang kecil. Disimpulkan bahwa membrane dengan ukuran pori 33 mikrometer memberikan rejeksi membrane lebih tinggi dibandingkan membrane dengan ukuran pori 80 mikrometer. Konsentrasi awal umpan mempengaruhi fluks dan rejeksi serta mempengaruhi pilihan kita dalam memilih jenis membran yang digunakan. Selama proses filtrasi, terjadi perubahan bentuk atau deformasi partikel minyak melewati slot atau pori membrane yang diamati melalui distribusi ukuran partikel.
\end{abstract}

Kata kunci: emulsi, mikrofiltrasi, membran berslot

*corresponding author 


\section{Introduction}

Recently, water containing dispersed oil has become of interest to many industries. Oil contaminated water can be found in many industries, including metal finishing, food, textile, and petroleum industries. The presence of dispersed oil in water can be harmful to aquatic life, as it attenuates light and perturbs normal oxygen transfer mechanisms. In the petroleum industry, oilin-water emulsion is mainly produced in the recovery of crude oil. The oil-in-water emulsion produced in crude oil recovery can cause problems at different stages of the production in petroleum industry. Produced water cannot be injected again into the well or discharged directly into the receiving body of water, because it contains high concentration of oil, grease and suspended particles. Because of this problem, such industries have tried to separate oil from water before the discharge of the water into the environment or reuse in the recovery of crude oil by reinjection into the oil bearing strata. Many methods have been carried out to separate oil from water in the petroleum industry. Such methods are chemical demulsification, gravity or centrifugal settling, pH adjustment, filtration, heat treatment, membrane separation and electrostatic demulsification.

Among the separation methods, membrane processes are increasingly being applied to separate oil from water. Many researchers have tried to investigate the application of microfiltration and ultrafiltration in separation of oil in water emulsion. There have been many developments and innovations in separation of oil-in-water emulsion using membranes.

Several studies have been conducted to prove that membrane technology, especially ultrafiltration and microfiltration, are suitable for treating oil-in water emulsion. Hlavacek (1995) investigated membrane coalescence to separate the two phases of an industrial emulsion from the aluminum industry. Demulsification process occurred when the emulsion permeated through a microfiltration membrane and it was found that the oil concentration in the lower layer of the permeate was as low as 30 ppm compared to $30,000 \mathrm{ppm}$ in the original emulsion. Then, using a pilot plant fitted with a $0.2 \mu \mathrm{m}$ microfiltration membrane of $1 \mathrm{~m}^{2}$ filtration area, it was shown that the process was reliable during 4 weeks of operation.

Ohya et al. (1998) investigated the effects of average pore size in porous glass tube membranes on the performance of the cross flow microfiltration using oil-in-water emulsions. The flux decline with filtration time was divided into 2 stages. The filtration mechanism in the first stage can be explained by a type of blocking filtration model and the second stage by the cake filtration model. According to the pore size, blocking filtration mechanisms are different, for $0.27 \mu \mathrm{m}$ pore diameter, complete blocking filtration occurred, for $0.75 \mu \mathrm{m}$ pore diameter, intermediate blocking filtration occurred, while for $1.47 \mu \mathrm{m}$ pores diameter, standard blocking filtration occurred. The transition time from blocking to cake formation occurred around 10 minutes for all membranes with different pore sizes. Oil rejection was found to decrease with time initially, but as soon stabilized at a constant level. Surfactant transmission was reported as $49 \%$ for $0.27 \mu \mathrm{m}$ membrane, $80 \%$ for $0.75 \mu \mathrm{m}$, and $99 \%$ for $1.47 \mu \mathrm{m}$ membrane.

Another study has been conducted using cross flow microfiltration with rapid back pulsing to remove suspended solids and dispersed oil from an aqueous stream by Ramirez and Davis (1998). Experiments on clay suspensions demonstrate that rapid back pulsing can maintain the permeate flux at a level which is more than 10 fold over the long term flux in the absence of back pulsing, without any reduction in the permeate quality. Experiments using dilute oil-in-water dispersions showed that rapid back pulsing can increase flux by up to 25 times, but can't be maintained over the life of the membrane.

In other experiments Holdich et al. (1998) tried to use true surface filters which had narrow pore size distributions and maximum pore diameters of 6.8 and 8 ? $\mathrm{m}$ to separate oil emulsions of drop diameters similar, or below, those used in the development work undertaken for the testing of hydro cyclones in the North Sea oil industry. The filters operated successfully and provided stable flux rates and rejections up to $96 \%$, under a variety operating conditions. The operating pressure required to produce permeate flow was a small fraction of that needed when filtering with conventional microfiltration membranes. For some tests the filter tubes contained tightly 
fitting helices of pitches: 14,42 and $70 \mathrm{~mm}$ to induce rotational flow to minimize deposition of oil drops suspended in water. For these experiments, filtrations were run under conditions of both constant flux and pressure, and this filtration process needed low values, ranging from 3 to $9 \mathrm{kPa}$. Another experiment using true surface filters conducted by Cumming et al. (1999) to treat oil-in-water emulsion stabilized by polyvinyl alcohol with drops diameter between 1-40 $\mu \mathrm{m}$. The filter tube was cylindrical with a central rod supporting an annular helix of 14 $\mathrm{mm}$ pitch. The filters were tested at a fixed rate of permeate flux and gave similar rejections whether the more open end or tighter end of the pores faced the challenge emulsion. However, the trans membrane pressure was $10 \%$ lower with the larger ends of the pores facing the challenge emulsion. An emulsion with a significant number of large drops gave a rejection above $80 \%$ at $2 \mu \mathrm{m}$ drops whilst a finer emulsion had a $50 \%$ cut-off just below $5 \mu \mathrm{m}$. The true surface filters exclude the possibility of internal fouling of the filter. Cumming et al. (2000) have also investigated microfiltration of oil using a stirred cell fitted with Nuclepore filters with pore sizes of 2, 5, 8 and $10 \mu \mathrm{m}$. The filters are produced by nuclear bombardment followed by chemical etching and can be classified as true filters because they have pores which pass directly through the filter from one side to the other side. A simple theory based on interfacial tension, contact angle and pore size is described and the results compared with experimental results, which treated oil emulsion drop size in the range $1-40 \mu \mathrm{m}$ stabilized by polyvinyl alcohol. There is a good similarity between model and experiment for the $2 \mu \mathrm{m}$ filter, but the model reliability decreased with increasing pore size. Sutrisna and Farid (2008), Sutrisna et al. (2006), and Sutrisna et al. (2005) were also tried to separate oil from water using slotted surface filter in cross flow mode by applying rotation of membrane. They found that the squeezing of an oil drop in the slot is really determined by the pressure applied and velocity of the surrounding fluid. A mathematical model to explain the interaction of oil drop and slot of membrane was also developed by Kosvintsev et al. (2007).

From many studies and research which have been conducted by many researchers to separate oil-in-water emulsion, it can be suggested that a further study of separation of oil from water using membrane is still needed, especially to enhance the flux of permeate and the rejection coefficient. This research uses true surface filter microfiltration membranes to separate oil from water because true surface filters have pores which pass directly through the filter from one side to the other side, so it will exclude the possibility of internal fouling of the filter. The surface of metal true surface filter or slotted pore filter can be seen in figure 1.

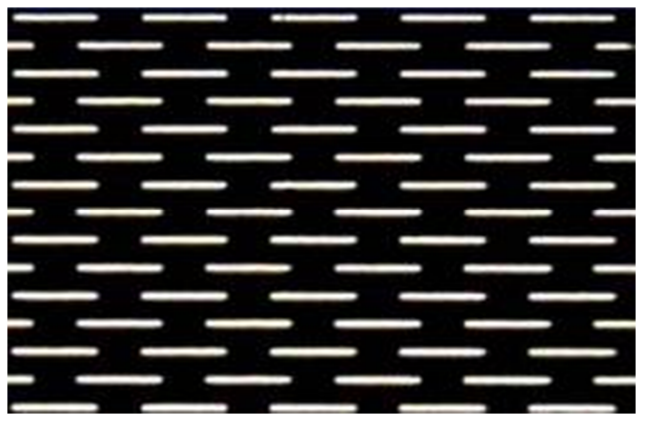

Figure 1. Surface of metal true surface filter

\section{Methodology}

This research has been done by varying slot width or pore of membrane and concentration of kerosene or crude oil. Feed emulsion was produced by mixing kerosene or crude oil with distilled water with initial oil concentration of $6.25 \%-v ; 10 \%$-vol; and $13.75 \%$-vol. $1 \%$-w of SPAN 80 was added to the feed emulsion as surfactant. The feed emulsion was then filtered through slotted filter or membrane with pore size of 33 and 80 microns in a dead end mode of operation. The membranes used in this experiment were made from aluminum using tracketching method and the thickness was 1 micron. During each experiment, flux and oil rejection were analyzed. Flux was measured by counting permeate volume and time required using measuring glass and timer, while oil rejection was measured by measuring turbidity of feed and permeate using UV-VIS Spectrophotometer Lambda EZ 150. Size distribution of oil particles was recorded and measured using Optica trinocular microscope with 400 times magnification and Microsoft Windows Paint program for image processing. The 
percentage oil rejection was calculated using formula (1).

$\%$ Oil Rejection $=100 \times$ (Turbidity of feed Turbidity of permeate)/(Turbidity of feed)

The schematic diagram of equipment used in filtration experiment can be seen on figure 2 .

\section{Results and Discussion \\ 3.1 Analysis of flux}

In this experiment, Trans Membrane Pressures (TMPs) were kept constant during the experiment, so the value of fluxes can be compared in various conditions. To separate oil from water using 33 microns membrane, the TMPs used were $33 \mathrm{mbar}$, while for 80 micron membrane we used TMPs of 14 mbar. Very small TMPs used in this experiment are one advantage of slotted pore membrane, where the structure of pore in slotted pore membrane will give higher flux than circular pore membrane. This is because they have extremely high area of filtering pores; i.e. the total open area on the filter surface can be as high as $33 \%$. When filtering on slotted pores the oil drop sitting on the filter no longer experiences the full pressure differential of TMP acting to force the drop through the slotted pore. It is possible for liquid to enter the permeate by flowing around the drop, as the drop does not plug off the entire slot. In this case, the force acting on the drop to push it into the permeate side is the liquid drag force of the permeate liquid passing around the stationary drop. This advantage will be very useful if we want to produce higher capacity or to scale up because it will consume lower energy to pump the feed to enhance the flux or capacity of product. Therefore the TMP should be controlled to prevent oil particles from moving from feed side to the permeate side. Figure 3 shows flux-membrane pore size curve for this experiment, where the value of flux has unit of $\mathrm{L} / \mathrm{m}^{2} \cdot \mathrm{h}$.

Based on the value of initial flux in figure 3 , it can be seen that flux decreased with the increase of feed concentration. During microfiltration of oil-in-water emulsion, there are blocking and non blocking conditions. In short period after the experiment was conducted, there was nonblocking condition, and where the movement of kerosene and crude oil particles was only affected by shear force generated on the surface of the membrane by rotation of mixer and also by permeates drag force. After that, there is the formation of a secondary membrane often called dynamic membrane on top of the primary membrane. This secondary membrane is always formed, whether automatically or by design from constituents in the feed. The formation of the secondary membrane will alter the performance of the primary membrane, in terms of flux and rejection. In this experiment, the secondary membranes will influence the performance of true surface filter in filtering the feed emulsion although the filter will exclude the possibility of internal fouling. It means that in this filter the secondary membrane will be formed and its formation depends on several factors, such as feed concentration and membrane pore size.

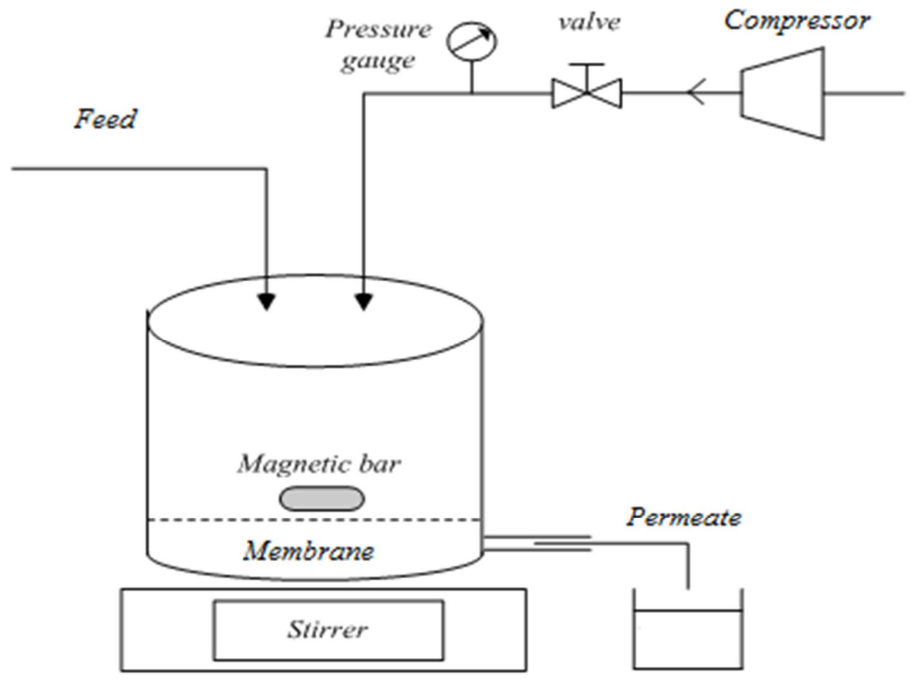

Figure 2. Schematic diagram of equipment used in filtration experiment 


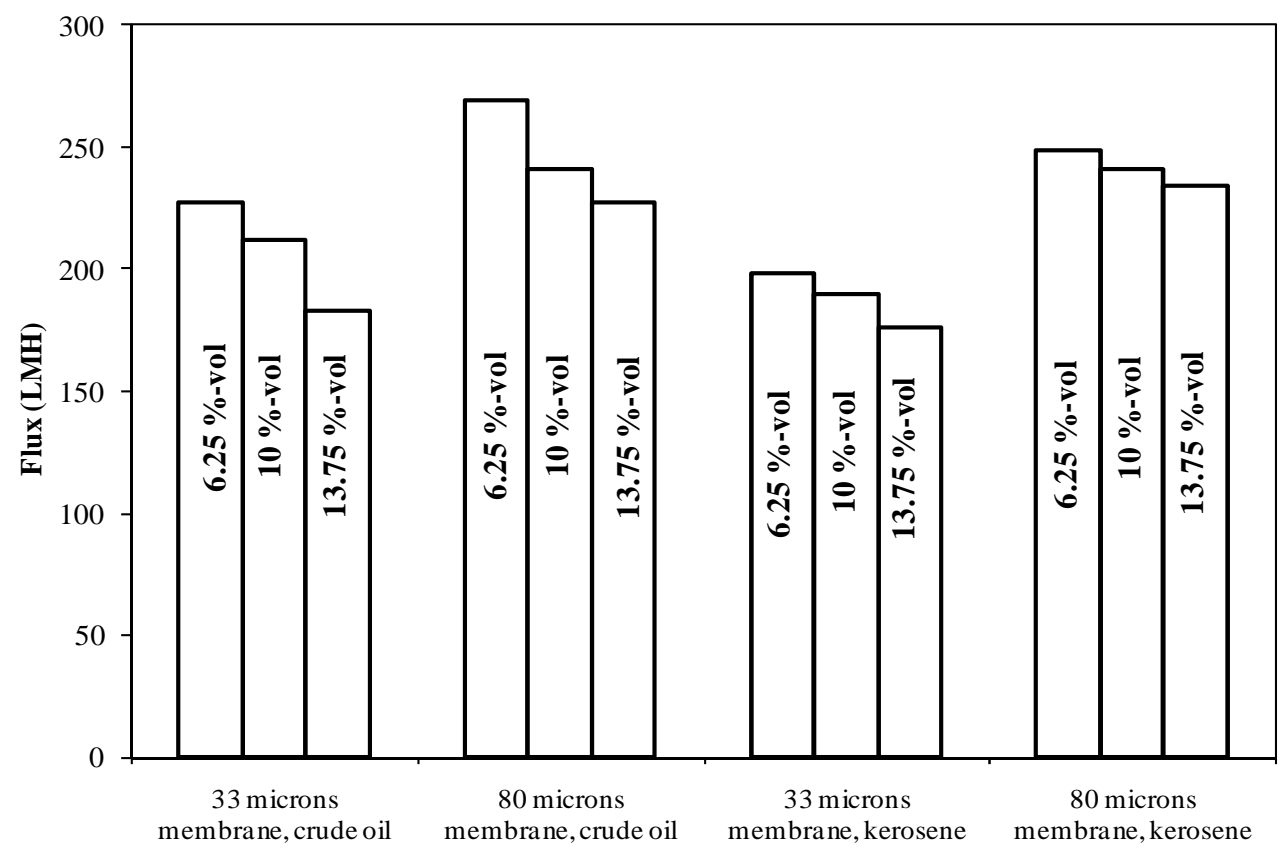

Figure 3. Flux-membrane pore size curve for crude oil and kerosene filtration using different membrane pore size

After the formation of dynamic membrane, the value of flux will be also affected by that second layer on the surface of membrane. The thicker the layer, the lower the flux during the experiment. For higher concentration of crude oil (13.75\%-vol), layer of dynamic membrane was thicker than other concentration and the flux will decrease about $60 \mathrm{~L} / \mathrm{m}^{2} \cdot \mathrm{h}$ after 8 minutes. This may be regarded as a beneficial effect, but this type of filtration behavior is usually associated with increasing filtration pressure, or decreasing filtration flux rates. Under these circumstances, the filtration is determined by the characteristics of the secondary membrane formed on the surface of the original slotted pore filter and, to some extent, the nature of the original slotted pore filter becomes less relevant. It is the intention of the slotted pore filter design that the filtration is determined by the nature of the slotted pore filter, and not the deposit on it.

Another phenomenon that can be observed from figure 3 is high flux for crude oil-in-water filtration experiment. Values of flux for crude oil-in-water filtration using 33 microns membrane were above $200 \mathrm{~L} / \mathrm{m}^{2} \cdot \mathrm{h}$, while for kerosene-in-water filtration using the same membrane, was below $200 \mathrm{~L} / \mathrm{m}^{2} \cdot \mathrm{h}$. Crude oils can vary greatly in composition, viscosity, density, and flammability. They can be found in a continuum ranging from highly flammable, light liquids (similar to gas condensate), to highly viscous and heavy tarlike materials. Organic compounds range from methane to extremely heavy hydrocarbon molecules with up to 80 carbon atoms. The chemical composition of crude varies between regions and even within the same geological formation. During the experiment, crude oil-in-water emulsion was easier to mix than kerosene-in-water emulsion, which is an indication that crude oil has some surfactants in itself. So the interaction of crude oil particle and surface of membrane was more intense than particle of kerosene, especially for high concentration of oil, which will increase the thickness of dynamic membrane. This phenomenon was observed in figure 3, where the decrease of flux of kerosene-in-water filtration was smaller than the decrease of flux of crude oilin-water filtration if the feed concentration was increased.

\subsection{Analysis of Oil Rejection}

Microfiltration membranes, which were used in this experiment, were developed to overcome some problems faced in circular pore membranes or conventional membranes. Performance of conventional membrane is only determined by depth mechanism of filtration so particles will be captured in the matrix of filter and flux will 
decrease and/or TMP will increase. Width of slot in slotted pore membrane will determine its performance, where particles with diameter larger than membrane pore size will not appear in the permeate side as long as TMP does not exceed the critical or maximum pressure, which will make the particles squeeze into the permeate side. In dead end filtration, the formation of secondary membrane brings about some advantages, such as: the rejection of particles becomes better than that of 'naked' membrane and there is a certain degree of retention of species, which are intended to pass through the membrane. Because of that, it will be very useful to also analyze the rejection curve for this experiment.

As the secondary membrane hindered the interaction between oil drops and the surface of membrane, we can expect that the rejection curve obtained from experiment at high feed concentration will be higher than at low feed concentration. This hypothesis was confirmed by \% rejection curve on figure 4 . Oil rejection for $13.75 \%$-vol was always higher than oil rejection for $6.25 \%$-vol and $10 \%$-vol. At high feed concentration, there will be much more oil particles dispersed in water, so the possibility of the drops to interact with membrane surface will be more intense.

The formation of a secondary membrane in this experiment was determined by many factors, such as the size distribution of oil drops in the feed emulsion, membrane pore size, and also by TMP used in the experiment. TMP used in this experiment was kept constant at very low pressure, i.e. 33 mbar for 33 microns membrane and 14 mbar for 80 microns membrane. Theoretically, a high TMP will increase the opportunity of oil drops to move on to the surface of membrane and to block the membrane. Finally, the formation of a secondary membrane at high TMP will be take place more readily than at low TMP.

Experiment with 33 microns membrane pore size give better oil rejection than experiment with 80 microns membrane pore size. This is because the possibility of formation of dynamic membrane in 33 microns membrane pore size was higher than 80 microns membranev. Choice of membrane pore size has significant impact on the formation of dynamic membrane, but it has to be analyzed carefully as oil drop is not a rigid particle so it can be squeezed through the pore of membrane if we use high TMP. Theoretically, drops with diameter smaller than the slot width will pass through the slot but drops with diameter larger than the slot width will either be rejected or deform and squeeze through the slot. This squeezed drop reduces the separation efficiency. Many factors affect the squeezing of these big drops, such as velocity of liquid in the feed and physical properties of the drop and filter media. There will be a critical ratio of diameter of the drop, or bubble, (D) and slot width (h). It means that beyond this critical $\mathrm{D} / \mathrm{h}$, the pressure needed to squeeze the drop or bubble will decrease. It

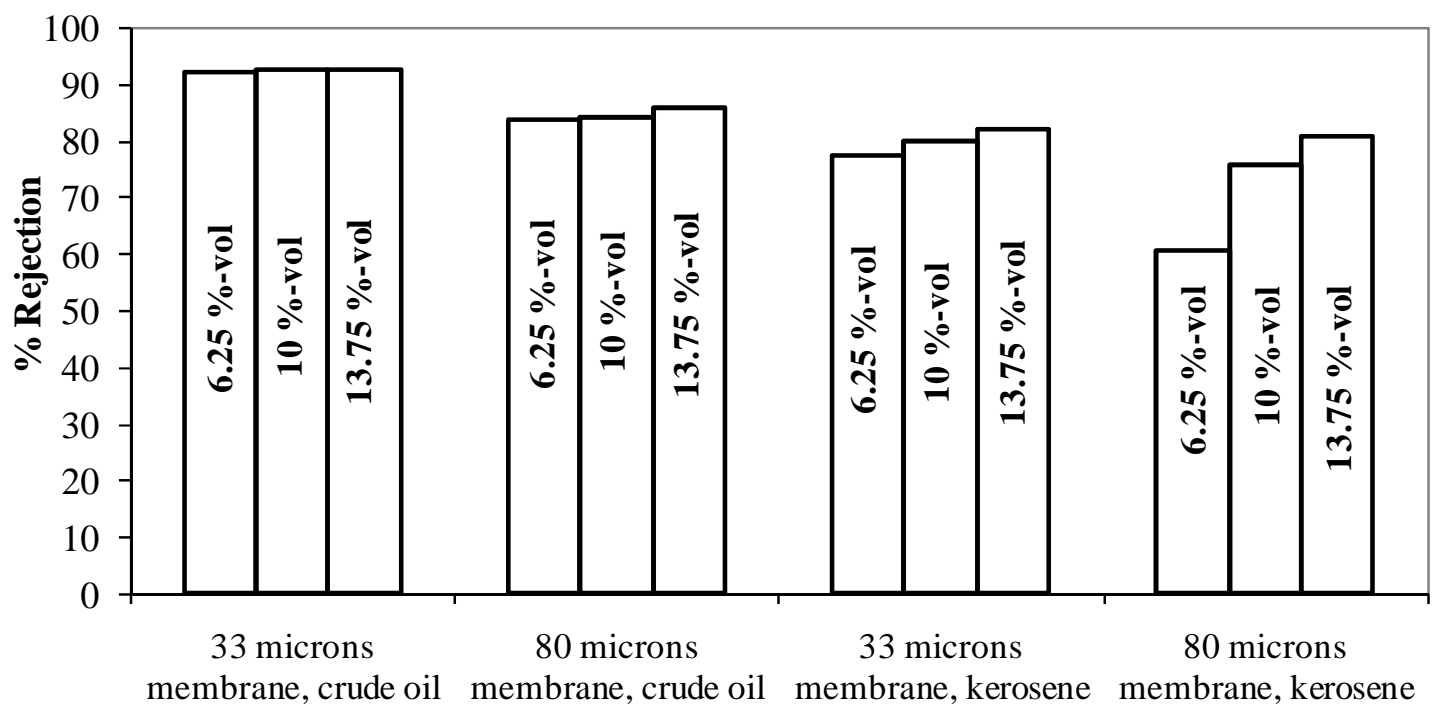

Figure 4. Oil rejection curve for crude oil and kerosene filtration using different membrane 
means that the choice of membrane pore size to separate oil drops from water must be followed by the determination of critical pressure or critical feed velocity used in the experiment. In this research, TMP used have been optimized so it can be concluded that at higher TMP there will be more oil particles appear in the permeate side.

From table 1, it can be observed that oil rejection decreased during the experiment. In the experiment, perfect mixing condition happened on the below side of emulsion, while on the upper side the concentration of oil was high because oil particles tend to move to the surface of emulsion. At the beginning of filtration, there was only a small amount of oil particles in the permeate side because oil concentration on the surface of membrane was still low. But after a few minutes the surface of emulsion approached the surface of membrane and the opportunity of oil particles to squeeze through pores of membrane was bigger.

The decreased of oil rejection also can be observed through microscopic observation. It can be observed that the number of oil particles in permeate increased during the experiment. Figure 5 and 6 show microscopic pictures of crude oil particles with feed concentration of $13.75 \%$-vol, which have been filtered using 80 microns membrane pore size.

From figures 5 and 6 it can be seen that sizes of crude oil particles in permeate side were larger than in feed side. It is caused by the absence of surfactants in the experiment, so oil particles tend to find similar particles and then coalesce to make bigger particles.

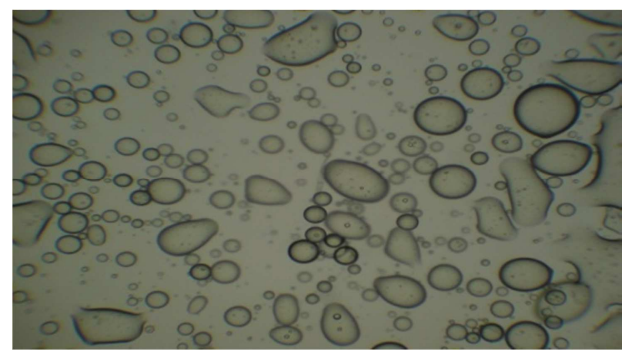

Figure 5. Crude oil-in-water emulsion in feed

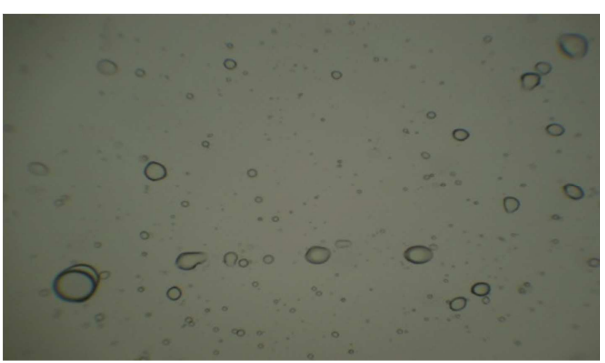

Figure 6. Permeate after 6 minutes

\subsection{Particle Size Distribution}

Size distribution of particles in feed and permeate during the experiment is very important to analyze the performance of membrane. Size distribution can also be used to prove that the oil particles are not rigid and they can deform through the pore of the membrane. In addition, from the size distribution we can also predict the critical pressure which is appropriate for oil filtration

Table 1. Final Flux and \% Oil Rejection During Experiment

\begin{tabular}{|c|c|c|c|c|c|}
\hline \multirow[b]{2}{*}{ Type of feed emulsion } & \multirow{2}{*}{$\begin{array}{l}\text { Pore of } \\
\text { membrane } \\
\text { (microns) }\end{array}$} & \multirow{2}{*}{$\begin{array}{l}\text { Feed } \\
\text { Concentration } \\
\text { (\%-volume) }\end{array}$} & \multirow{2}{*}{$\begin{array}{l}\text { Final flux } \\
\left(\mathrm{L} / \mathrm{m}^{2} \cdot \mathrm{h}\right)\end{array}$} & \multicolumn{2}{|c|}{$\%$ Oil Rejection } \\
\hline & & & & $\begin{array}{l}\mathrm{t}=2 \\
\text { minutes }\end{array}$ & $\begin{array}{l}\mathrm{t}=8 \\
\text { minutes }\end{array}$ \\
\hline \multirow[t]{6}{*}{ Crude Oil-in-Water } & 33 & 6.25 & 170 & 93.02 & 89.53 \\
\hline & & 10 & 154 & 93.39 & 91.33 \\
\hline & & 13.75 & 137 & 92.83 & 91.72 \\
\hline & 80 & 6.25 & 190 & 84.62 & 83.74 \\
\hline & & 10 & 183 & 85.39 & 80.55 \\
\hline & & 13.75 & 163 & 87.76 & 84.01 \\
\hline \multirow[t]{6}{*}{ Kerosene-in-Water } & 33 & 6.25 & 155 & 79.14 & 73.87 \\
\hline & & 10 & 148 & 82.15 & 75.39 \\
\hline & & 13.75 & 137 & 84.44 & 81.47 \\
\hline & 80 & 6.25 & 199 & 65.63 & 53.42 \\
\hline & & 10 & 196 & 78.55 & 74.51 \\
\hline & & 13.75 & 181 & 82.42 & 80.83 \\
\hline
\end{tabular}


at different feed concentration. From analysis of size distribution of particles using microscope pictures for kerosene-in-water emulsion with feed concentration of 80,000 ppm, which was filtered using 80 microns membrane, we can see the size distribution in figure 7 and 8.

Figure 7 and 8 can give a quick picture of size distribution of oil particles in feed and permeate. As can be seen for 80 microns membrane, in feed emulsion, diameters of oil particles lie between 5 microns up to more than 100 microns. But this distribution then move to less than 25 microns in the permeate side. This is an indication that oil particles are not rigid and they can be deformed when they are pushed through the pores of membrane. As a result, the big particle will deform and change to more than one small particles and these small particles will appear in the permeate side and can affect the value of oil rejection. The deformation of oil particles can be influenced by TMP or velocity of feed emulsion.

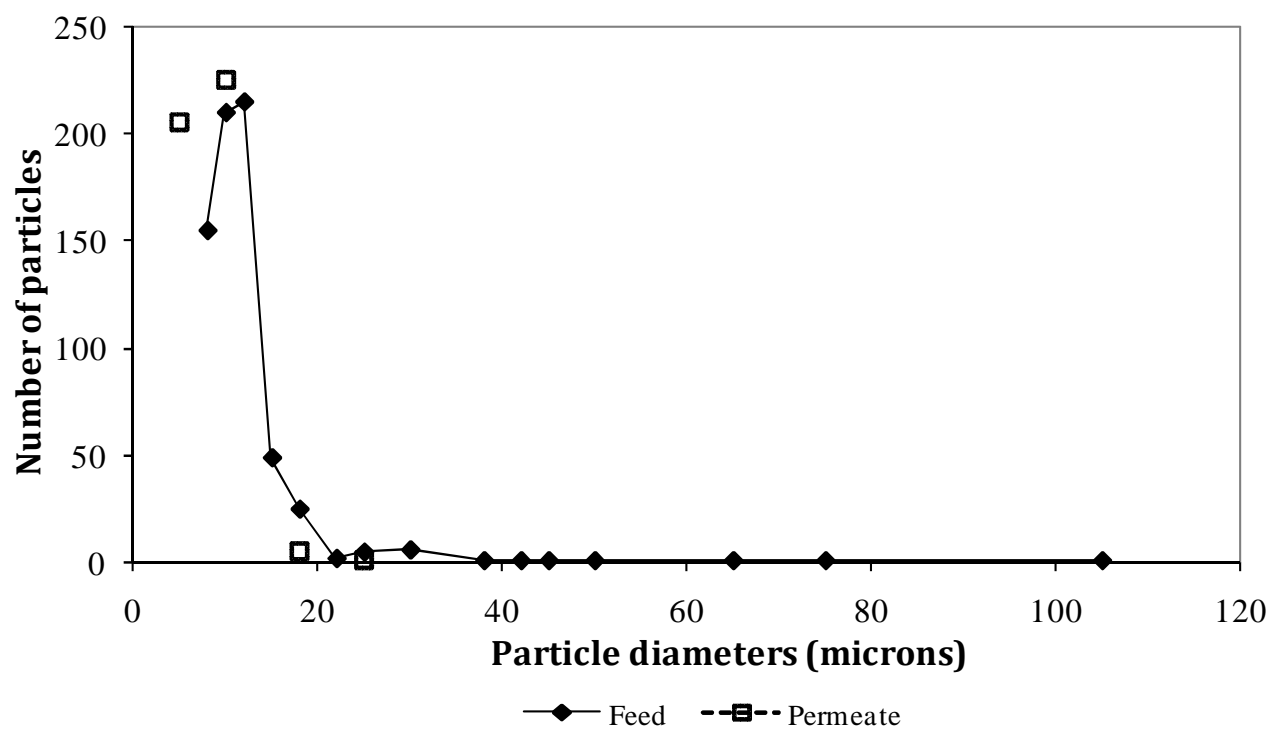

Figure 7. Size distribution of kerosene particles during filtration of 80,000 ppm kerosenein-water emulsion using 80 microns membrane

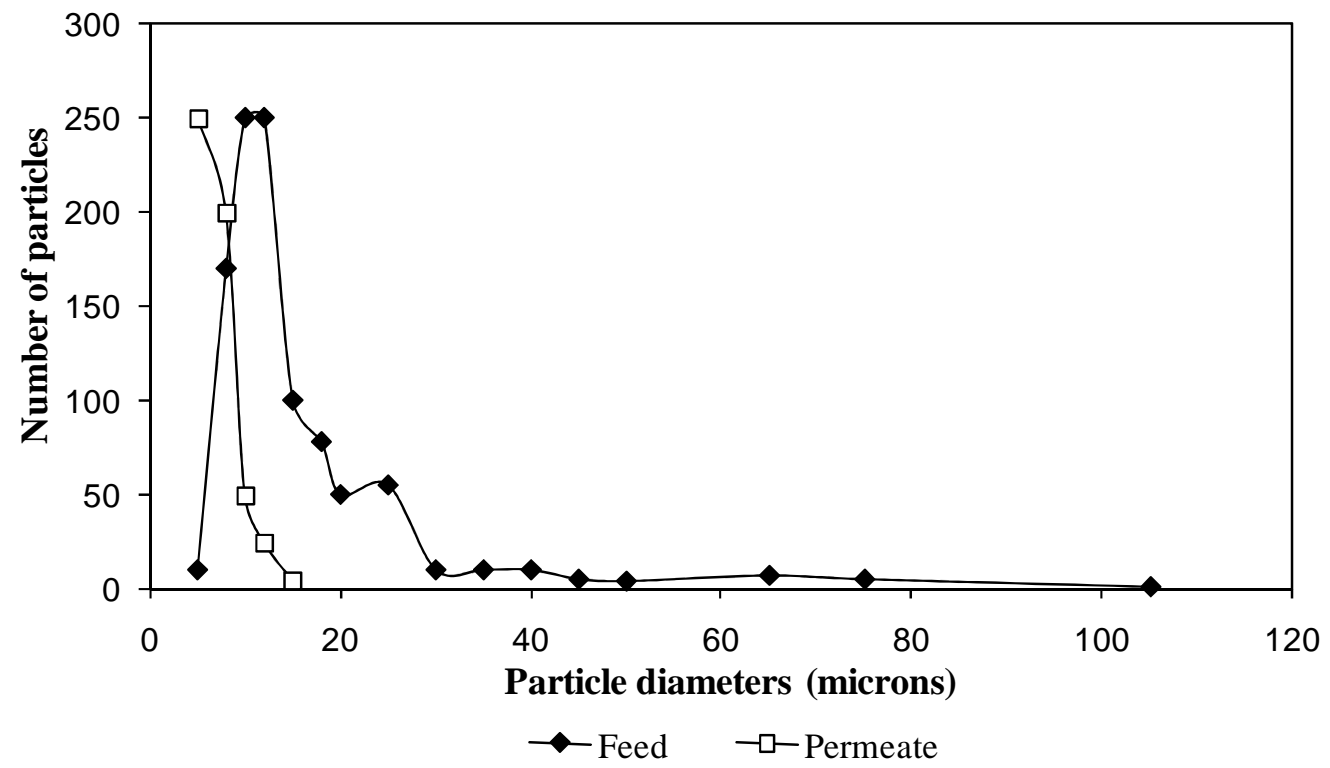

Figure 8. Size distribution of kerosene particles during filtration of 80,000 ppm kerosenein-water emulsion using 33 microns membrane 


\section{Conclusion}

This study has been conducted to separate oil from water in a system of oil-inwater emulsion using slotted pore membrane in a dead end mode of operation. The membrane has a superior performance in producing high flux in a very small TMP because the movement of oil drops is only influenced by permeate drag force instead of capillary force. Based on the slot width it can be concluded that 33 microns membrane pore size gives better oil rejection than 80 microns membrane pore size. Initial concentrations of challenge emulsion also influence the value of flux and oil rejection, which will also influence the decision to choose suitable membrane in relation with the hydrophilicity of the membrane. During microfiltration process, there was deformation of oil particle through slot of membrane, which can be analyzed by observing size of oil drops in feed and permeate.

\section{Acknowledgement}

The financial support from The Directorate of Higher Education (DIKTI) of Indonesian Government through Hibah Bersaing Project year 2010-2011 is gratefully acknowledged.

\section{References}

Cumming, I. W.; Holdich, R. G.; Smith, I. D., The rejection of oil using an asymmetric metal microfilter to separate an oil in water dispersion, Water Research, 1999, 33(17), 3587-3594.

Cumming, I.W.; Holdich, R.G.; Smith, I.D., The rejection of oil by microfiltration of a stabilised kerosene/water emulsion, Journal of Membrane Science, 2000, 169(1), 147-155.

Hlavacek, M., Break-up of oil-in-water emulsions induced by permeation through a microfiltration membrane, Journal of Membrane Science, 1995, 102, 1-7.
Holdich, R. G.; Cumming, I. W.; Smith, I. D., Crossflow microfiltration of oil in water dispersions using surface filtration with imposed fluid rotation, Journal of Membrane Science, 1998, 143(1), 263-274.

Kosvintsev, S. R.; Sutrisna, P. D.; Cumming, I. W.; Holdich, R. G.; Mason, G., The passage of deforming drops through a slotted microfilter, Chemical Engineering Research and Design, 2007, 85(4), 530-536.

Ohya, H.; Kim, J. J.; Chinen, A.; Aihara, M.; Semenova, S. I.; Negishi, Y.; Mori, O.; Yasuda, M., Effects of pore size on separation mechanism of microfiltration of oily water using porous glass tubular membrane, Journal of Membrane Science, 1998, 145(1), 1-14.

Ramirez, J. A.; Davis, R. H., Application of cross-flow microfiltration with rapid backpulsing to waste water treatment, Journal of Hazardous Materials, 1998, 63(23), 179-197.

Sutrisna, P. D.; Farid, S., Analisa penurunan fluks pada proses pengolahan limbah emulsi minyak dalam air dengan membran mikrofiltrasi slotted true surface filter (STSF), Seminar Hasil Penelitian Dosen Muda Dikti, Surabaya, 16 December 2008.

Sutrisna, P. D.; Holdich, R.G.; Kosvintsev, S.R.; Cumming, I.W., Rotating cylinder microfiltration of oil-in-water emulsion using novel slotted pore filter, Journal of Applied Membrane Science and Technology, 2005, 3, 15-28.

Sutrisna, P. D.; Winoto, R. G.; Holdich, S. R.; Kosvintsev, I. W.; Cumming, Slotted Pore Microfiltration of Crude Oil-in-Water Emulsion, Proceeding of $13^{\text {th }}$ Regional Symposium on Chemical Engineering (RSCE), Singapore, 3-5 December 2006, pp. 369-370. 